Servicio de publicaciones y difusión científica (SPDC), Universidad de Las Palmas de Gran Canaria, Parque CientíficoTecnológico, Edificio Polivalente II, C/ Practicante Ignacio Rodríguez, s/n Campus Universitario de Tafira 35017 - Las Palmas de Gran Canaria, Spain.

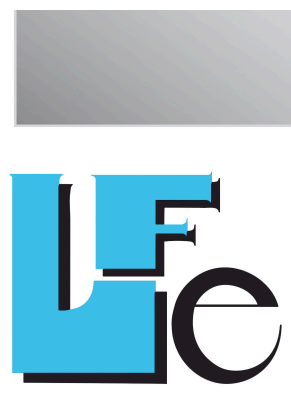

Revista de Lenguas para Fines Específicos

\section{Revista de lenguas para fines específicos}

eISSN: $2340-8561$

Journal information, indexing and abstracting details, archives, and instructions for submissions:

https://ojsspdc.ulpgc.es/ojs/index.php/LFE/index

\section{Luego and después with a textual}

function: Discursive use and variation in the Panhispanic educated norm

\section{Juana Santana Marrero}

Universidad de Sevilla, Departamento de Lengua Española, Lingüística y Teoría de la Literatura. Facultad de Filología. C/ Palos de la Frontera, s/n 41004 Sevilla (Spain).

Article first published online: 27 July 2015.

Article published online with DOI added: 5 April 2016. 


\title{
Luego and después with a textual function: Discursive use and variation in the Panhispanic educated norm
}

\author{
Juana Santana Marrero ${ }^{1}$
}

Universidad de Sevilla

\begin{abstract}
One of our previous works had as its aim to analyse the behaviour of luego and después in the speech of Seville. The results obtained were significant, but they required an expansion of the material subject to analysis; hence our decision to study luego and después with a textual function in the Macrocorpus of the Linguistic Educated Norm in Major Cities of the Hispanic World. The focus will be specifically placed on their role as time connectors and as information-structuring units. This will allow us to check whether the patterns of variation and discursive behaviour observed so far are common to spoken Spanish as a whole, or whether diatopical or diastratic differences arise which help to shape the usage profile of these two alternating units.
\end{abstract}

Keywords: discourse markers, luego and después, variation, spoken Spanish, educated norm

\section{RESUMEN}

En un trabajo previo estudiamos el comportamiento de luego y después en el habla de Sevilla. Los resultados obtenidos fueron significativos, pero requerían ampliar el material de análisis. Para ello, en esta ocasión nos ocuparemos de la alternancia de luego y después con función textual en el Macrocorpus de la norma lingüística culta de las principales ciudades del mundo hispánico. Concretamente nos centraremos en su papel como conectores temporales y como estructuradores de la información. De este modo podremos comprobar si los patrones de variación y de comportamiento discursivo hasta ahora observados son

1 Corresponding author - Universidad de Sevilla, Departamento de Lengua Española, Lingüística y Teoría de la Literatura. Facultad de Filología. C/ Palos de la Frontera, s/n 41004 Sevilla (Spain).

Email: jsantana@us.es 
comunes al español hablado en general o si se aprecian diferencias de carácter diatópico o diastrático que ayuden a perfilar el uso de estas dos variantes.

Palabras claves: Marcadores del discurso, luego y después, variación, español hablado, norma culta

The Macrocorpus de la norma lingüística culta de las principales ciudades del mundo hispánico [Macrocorpus of the Linguistic Educated Norm in Major Cities of the Hispanic World] (Samper, Hernández and Troya, 1998) is one of the main sources currently available to us when it comes to studying oral Spanish. Good evidence of this can be found in the large number of research works which have taken it as their starting point, particularly, those developed within the Proyecto de Estudio de la Norma Culta Juan M. Lope Blanch [Project for the Study of the Educated Hispanic Norm Juan M. Lope Blanch]. They all have contributed to the description of linguistic habits in the sociolect spoken by the population segment with a higher cultural level -one of the main references for normative decision-making. The research presented here goes along the lines of an approach aimed at identifying the linguistic strategies which are common among such speakers, seeking common patterns of action and, as the case may be, differences between the urban areas covered by the sample. More precisely, emphasis will be placed on the alternation between luego and después when they act on a textual level. This research complements another previous one dedicated to the study of educated speech in Seville (Santana in press) which revealed a number of usage patterns that, in our opinion, needed to be confirmed with a larger speech sample. The Macrocorpus is an ideal material for our purposes: either to corroborate or to refute the conclusions drawn from a smaller sample, or to check the possible existence of diatopical or diastratic constraints that might affect the aforesaid alternation.

\section{Discourse Markers and Variation}

The study of discourse markers stands out as one of the fields in Hispanic linguistics which has received the most attention during the last few decades. Research works keep proliferating from various perspectives, as can be seen in Loureda \& Acín (2010). However, some expert, authoritative voices have highlighted the need for a more in-depth analysis of these units from the context of variation, as already noted Martín Zorraquino (2006) -or in the words of Cortés (1988), "análisis cuantitativo" 'a quantitative analysis'. It must be said that not too many contributions have been made in this area, especially when compared to other aspects, although some interesting titles have actually been published (Carbonero \& Santana 2010, Valencia 
2014, among others). Little is yet known about the markers shared throughout the Spanish-speaking world or those which are specific to particular areas; and much also needs to be learnt about diastratic differences (sociocultural level, age and gender) in the utilisation of such linguistic units.

As suggested by Cortés (1988), this lack of research must be linked to the difficulty involved in combining the principles of variationist linguistics with the actual nature of discourse markers. To be more precise, this author claims that it is often difficult to succeed in proving that two or more of these units alternate, sharing the same discursive meaning and being used with an identical communicative intention. In other words, verifying that they are two ways of saying the same thing and, from there, trying to identify the specific linguistic or social factors which determine their variation. And this is mainly due to the fact that markers do not always provide the same discursive sense to the text; instead, a variety of inferential contents may develop in the context which makes it possible for one unit (bueno, entonces, pues, 0 sea, etc.) to fulfil different communicative functions. Under these circumstances, it is our conviction that markers can be studied from the perspective of variation. There are two possible approaches to this task: (a) semasiological (a marker is taken as a starting point, analysing its discursive values within a particular context and register and, subsequently, examining its distribution across the social groups considered); and (b) onomasiological (starting from a specific discursive function, an effort is made firstly to identify the formal units used to express such content, and then to check the possible existence of social constraints with regard to their utilisation).

Our paper has adopted a semasiological perspective where two units, luego and después, express the same discursive meaning: indicating that one event occurs subsequently to another or the continuation of a discursive contribution with respect to a previous utterance. As a matter of fact, these two units are often treated as equivalents, insofar as they are defined in exactly the same terms. Fuentes (2009: 105 and 204) tells us about them that "su valor básico es el de indicar posterioridad temporal entre las acciones narradas" "their value consists in indicating that one of the narrated actions takes place at a later moment than the other'. This semantic synonymy is the basis for the possible development of a variation-based research study where luego and después appear as alternating units and the use of one or another mainly depends on each speaker's choice. The motivation for this choice may either be found in linguistic or social parameters or otherwise be simply random and lacking any justification whatsoever. Finding a valid answer to this question is actually going to be one of the aims sought in this research. 


\section{Luego and Después: their Characterisation as Textual Units}

Luego and después have an adverbial origin -exactly the same as many other discourse markers (Fuentes 1996: 14). They are referential time adverbs which basically answer the question when? from a semantic point of view (RAE 2009: 2316), even though a locative sense has been attributed to them too (Kovacci 1999: 707).

The consultation of general dictionaries provides us with a basic description of the content conveyed by these two units. Thus, a main temporal meaning is given to luego in the DRAE (Anoche fuimos al teatro, y luego a una sala de fiestas 'last night we went to the theatre, and then to a nightclub'), although the DUE and the DEA also place it in spatial contexts (A continuación viene el buche, luego la molleja muscular y por fin el intestino 'following is the crop, then the muscular gizzard and finally the intestine'). The description that these lexicographical works offer for después is very similar: chronological succession (Bibiana... recorre toda la casa recogiendo cosas... Después entra también en la habitación 'Bibiana... goes through the house collecting things... After that, she also enters the room'); locative (Ya verás cómo los pueblos de después de Reinosa son más bonitos 'You will see that the next villages to Reinosa are more beautiful'); and, in the DRAE, also ordinal (Esquimes fue el mejor orador de Grecia después de Demóstenes 'Esquimes was the best orator in Greece, following Demosthenes'). Apart from this basic meaning, other contexts reveal nuances such as 'soon', 'without delay' and 'early' in the case of luego (Muy luego tocó las consecuencias 'Consequences were felt very soon') or 'immediately afterwards' in the case of después (A mitad de la calle hay una iglesia, y después está mi casa 'There is a church in the middle of the street, and my house is inmmediately afterwards'). Only those contexts which show the aforesaid meaning of chronological succession are of interest to us in this paper.

More specialised lexicographical works lead us towards a better-defined characterisation. Santos (2003: 434 and 327) distinguishes between luego and después as deictic adverbs and anaphoric deictics. The main difference between these two types is that the former places a content within a specific time situation, what will happen 'later' (Después te cuento lo que me dijo 'I'll tell you later what he told me'), whereas the latter establishes a connection between the 'chronological succession' meaning of the adverb and another event mentioned before ([...] examinó los cajones de la mesilla. Luego se dirigió a la puerta 'He examined the bedside drawers. Then he moved towards the door'). And, most importantly for this research, it can be deduced from the examples supplied by Santos that anaphoric deictics include those with a meaning that exceeds the sentence limits and are placed on a textual level. Their mission consists in showing how some events are subsequent to others, sometimes with additional senses such as contrast or addition. Apart from that, the author indicates that this group of anaphoric deictics 
can be part of an enumeration (or a list) where subsequent events are arranged after other preceding ones within a chronological sequence. According to Santos, "a menudo se corresponden con un primero anterior" "they often show a correspondence with a preceding primero' for this purpose (Primero hizo esto y luego lo otro 'First he made this one and then the other'). Expressed differently, formal marks are used to specify the exact moment when the events in a series take place.

Within this textual context already noted by Santos (2003), on which our focus will be placed from now on, Fuentes (2009: 105 and 204) suggests a dual role of these two particles: luego "puede usarse como conector temporal propiamente dicho o como ordenador discursivo en enumeración" "can be used as a time connector strictly speaking or as a discursive organiser on an enumeration', and después fulfils the function of showing "a) posterioridad en la realización de los hechos, b) en enumeración, c) posterioridad en la enunciación” ‘a) 'posteriority' in the occurrence of events; b) on an enumeration; and c) 'posteriority' in the utterance'. A reference will be made to time connectors (conectores temporales) in the first case, when the chronological succession is highlighted, and to information-structuring units (estructuradores de la información) in the second one, when the utterance contains enumeration or succession processes.

Martín Zorraquino and Portolés Zorraquino (1999: 4093) describe the connector as a type of discourse marker which "vincula semántica y pragmáticamente un miembro del discurso con otro miembro anterior" 'establishes a semantic and pragmatic link between one discourse member and another previous discourse member'. These authors distinguish three groups depending on the content that they supply to texts: additive, consecutive, and counter-argumentative. Following Fuentes (1996: 22), it seems to us that a new group needs to be included: those which show the timing or chronological distribution of events within the discourse and often include the facts in a narration or a story, namely, time connectors. Their mission is to place text contents along a timeline.

$$
\begin{aligned}
& \text { Luego nos mudamos a la dirección actual. Y después en... mil } \\
& \text { novecientos cuarenta y cuatro pasamos cerca de un año en Pueblo } \\
& \text { Libre y luego nosotros, mis hermanas y yo, regresamos a República } \\
& \text { Portugal. (LI-09) } \\
& \text { 'Then we moved to our current address. And later... in nineteen and } \\
& \text { forty four we spent about a year in Pueblo Libre and then, we, my } \\
& \text { sisters and I, returned to Portugal'. }
\end{aligned}
$$

A second textual function for luego and después is the one where they act as information-structuring units. These markers are used to "señalar la organización informativa de los discursos" 'portray the informative organisation of discourses' 
(Martín Zorraquino and Portolés 1999: 4080). Now a visible difference appears with regard to time connectors: there has been a movement from the utterance level, from the chronological succession of events occurring in the linearity of time, to that of enunciation. This new function signals information continuity and development in texts. In other words, speech acts are of greater interest to us than the succession of contents: the sequencing or order on the 'saying' plane is marked. The meaning of luego and después is no longer referential and now becomes procedural, as both units guide the interlocutor to indicate what is said later, the information that follows what has been previously said. Martín Zorraquino and Portolés (1999: 4060) explain that these units "van abandonando su significado conceptual y se especializan en otro de procesamiento" 'gradually abandon their conceptual meaning and specialise in another processing-related one'. Cortés and Camacho (2005: 147) refer to a "sedimentación discursiva" 'discursive sedimentation', defined as "un proceso mediante el cual una unidad lingüística asume un valor o significado discursivo específico, perdiendo el valor semántico que tuviera, al menos en ese momento de significar, con el nuevo valor" ‘a process through which a linguistic unit takes a specific discursive value or meaning, thus losing the semantic value that it used to have, at least in that moment of signifying, with the new value'.

$$
\begin{aligned}
& \text { Es un... es una ciudad que a mí me gustaría muchísimo vivir. Me parece } \\
& \text { estupenda la gente de Washington. [...] Y luego los alrededores, toda } \\
& \text { esa parte de Virginia, la casa de George Washington, [...] Y después } \\
& \text { tienen un grupo de señoras voluntarias que trabajan para cuidar los } \\
& \text { museos (BA-13) } \\
& \text { 'It's a... it's a city where I would like very much to live. I think that people } \\
& \text { from Washington are great. [...] And then the surroundings, all that part } \\
& \text { of Virginia, the house of George Washington, [...] And furthermore they } \\
& \text { have a group of volunteer ladies who work taking care of museums'. }
\end{aligned}
$$

The group of information-structuring units contains the subgroup of organising markers (ordenadores) which "indican el lugar que ocupa un miembro del discurso en el conjunto de una secuencia discursiva ordenada por partes" 'indicate the place occupied by a discourse member within the whole of a discursive sequence ordered by parts' and "presentan el conjunto de esta secuencia como un único comentario y cada parte como un subcomentario" "present that whole sequence as a single comment, and each of its parts as a subcomment' (Martín Zorraquino and Portolés 1999: 4080). These particles are distributed into three groups: opening (en primer lugar, por un lado...), continuity or development (en segundo lugar, por otro lado...), and closing (en último lugar, finalmente...). Luego and después belong to the second group, insofar as they mark the progress of information, a continuation with respect to what has been said before. None of the works consulted (Garcés 1996, 2000, 2001, 2008; Portolés 2010) contains a thorough study about these two markers, the 
presence of which in specialised publications is usually confined to their inclusion on the list of continuity-ordering units (ordenadores de continuidad). Our concern on this occasion will be the analysis of their behaviour in educated spoken language as elements with a textual function: time connectors and information-structuring units. This will help us not only to identify their peculiarities in linguistic usage but also to monitor their variation as alternating units which share the same communicative intention.

\section{The Sample}

The Macrocorpus contains the transliteration of 168 speech samples from 12 cities around the Hispanic world: Bogota (BO), Buenos Aires (BA), Caracas (CA), La Paz (LP), Las Palmas de Gran Canaria (GC), Lima (LI), Madrid (MA), Mexico (ME), San Jose de Costa Rica (CR), San Juan de Puerto Rico (PR), Santiago de Chile (CH) and Seville (SE). There are altogether about 84 hours of oral speech interviews distributed in interviews lasting half an hour each with 14 subjects per city. The recordings, made between the 1960s and $1990 \mathrm{~s}^{2}$, followed the semi-structured survey methodology: a researcher channels the conversation towards everyday topics such as childhood, hobbies, work or the city of birth and residence, which can help to make the chat as relaxed and spontaneous as possible. The respondents, most of whom had completed their university studies, ${ }^{3}$ were classified according to criteria of age (4 people from the first generation, between 25 and 35 years of age; 6 from the second generation, between 36 and 55 years of age; and 4 from the third generation, 56 years old or older) and gender ( 7 men and 7 women).

The city abbreviation is provided first to indicate where the examples come from, followed by the informant number, knowing that 01 and 02 corresponds to men from the first generation; 03 and 04 to women from the first generation; 05,06 and 07 to men from the second generation; 08,09 and 10 to women from the second generation; 11 and 12 to men from the third generation; and finally, 13 and 14 to women from the third generation.

2 The fact that the material is not recent does not reduce the suitability of this sample. It was proved in a previous paper (Santana 2014) that the diachronic factor does not play a decisive role in the use of discourse markers.

3 The specific social circumstances of the time explain that some women in the older surveys were ladies who had no university studies but were regarded as 'educated' (high-class) mainly because they belonged to wealthy families or because they had married important and prestigious men. 
Our sample data showed the following quantitative results: ${ }^{4}$

\begin{tabular}{lllll}
\hline & \multicolumn{2}{l}{ Time connectors } & \multicolumn{2}{c}{ Information-structuring units } \\
\cline { 2 - 5 } & $\mathbf{N}$ & \% & $\mathbf{N}$ & \% \\
\hline Luego & 286 & 57.31 & 213 & 42.69 \\
Después & 414 & 59.40 & 283 & 40.60 \\
Total & 700 & 58.53 & 496 & 41.47 \\
\hline
\end{tabular}

Table 1. Global results

As can be seen, the time connector function was more recurrent. On the whole, después was the most frequently used variant in both discursive functions. A more detailed explanation of these data will be provided in the following sections.

\section{Luego and Después as Time Connectors}

Narrative fragments especially favour the use of this marker subset. During the Macrocorpus interviews, informants are often asked about events experienced throughout their lives (childhood, work, hobbies ...) -which the respondent tends to arrange chronologically. Luego and después are quite recurrent in oral texts when it comes to indicating chronological succession, as shown by their common use in our materials and by the fact that they are utilised at least once by a large majority of respondents $(142 / 168,84.52 \%)$. The most frequent variant to fulfil this role was después $(414 / 700,59.14 \%)$, although the frequency rate seems to be fairly balanced with respect to /uego.

Within the narrative-descriptive framework under study here, these two connectors are mostly used on enumerations of events that follow each other chronologically.

4 A decision was made to exclude from our count a number of cases where the interviewer's question clearly determined the informants' choice between luego and después -as shown by the fact that the beginning of their answers was formally very close to the question which had just been asked to them.

Enc.- ¿Y ya después, ya no las dirigen; ya las dejan que actúen libremente con los niños o...? Inf.- Sí. Ya después, ya... ya actúan ellas solas. (MA-10)

'Enc.- And later, they aren't led any more; they are allowed to act freely with children or...? // Inf.-. Yes. Later..., they already act on their own'

Some unfinished sentences in which the meaning of luego or después remained unclear were not taken into account either.

En feria, por la mañana lo que es bonito es el paseo de caballos y después... Pero la feria yo creo que cuando tiene más encanto es por la noche. (SE-04) 'Look, no. In the fair, in the morning, what is beautiful is the horse ride and later... But I think that when the fair has more charm is at night' 
Their aim consists in indicating that the content of the utterance that they are influencing happened subsequently to another with which a semantic-pragmatic connection is established. They act as a kind of hinge that joins the narrated facts, without specifying a particular time period; hence their tendency to be accompanied by other lexical elements which provide more accurate data about time location or duration.

$$
\begin{aligned}
& \text { Yo no me había desvinculado de la universidad desde el año cincuenta } \\
& \text { y uno, que ingresé como alumno, hasta el cincuenta y siete. Luego, } \\
& \text { desde... enero del cincuenta y siete, como profes... jefe de prácticas y } \\
& \text { profesor hasta el cincuenta y ocho. (LI-06)‘ } \\
& \text { I had not stopped being involved in the university since fifty one, when I } \\
& \text { joined as a student, up to fifty seven. Then, from... January fifty seven, as } \\
& \text { profess... head of practices and professor up to fifty eight'. }
\end{aligned}
$$

When luego and después appeared on enumerations, a reference was sometimes made to the moment when the series events took place: what happened first, later and last. Our attention here focuses on those cases where chronological ordering not only becomes evident from the information issued by the informant (the distribution of events across various life stages: childhood, youth and old age; the utilisation of dates ...), but is also highlighted by certain marks, grammaticalised on some occasions as time connectors which have come to specialise in fulfilling this discursive function: primero, al principio, finalmente, al final... However, this is by no means common in our materials. Garcés (1996: 53-54) explained that marking the different phases of the process appears as a more common feature of written texts. Data from Santana (2014) also confirm this quality. Only 39 examples of this type were recorded throughout our corpus. This figure suggests that non-elaborate speech follows several specific parameters, where the time sequencing of events narrated in a series is not usually indicated in an explicit manner -i.e. using markers.

$$
\begin{aligned}
& \text { Pues, primero fuimos a probarla un día, solamente por probarla, a Jerez, } \\
& \text { cuando estaba recien... Todavía no estaba inaugurada del todo, sino en } \\
& \text { algunos tramos... A Jerez, y después nos acercamos a Cádiz, y } \\
& \text { últimamente ya por la autopista entera tuvimos que ir a una reunión de } \\
& \text { pediatría (SE-05) } \\
& \text { 'Well, first we went to try it one day, just to try, to Jerez, when it was } \\
& \text { recent... It still was not fully opened, only in some sections... To Jerez, } \\
& \text { and later we went to Cadiz, and lately, when we had to go along the } \\
& \text { whole motorway to go to a pediatrics meeting'. }
\end{aligned}
$$

The main strategy used to identify the last event was the combination of $y$ or ya with luego or después (in 37 of the 39 cases mentioned above). Here the time connector indicates not only 'what happened later' but also 'what happened last'. 
Primero, es su... tiene un séquito que la defiende; después, tiene un marido al que se la entregan vestida de novia, y después se muere. (BO-

13)

'First, it is her... she has a cortege that defends her; later she has a husband whom she is delivered to in the wedding dress, and later she dies'.

The data obtained from the sample allow us to state that the time connectors luego and después often serve as instruments to describe the sequence of events in the narrative fragments which are typical of non-elaborate speech. So much so that they are hardly ever accompanied by other marks referring to the first or the last event recorded in a series and can even be used to indicate which event happened last, thus replacing marks more specifically meant for this purpose which could be expected in a planned text. The actual content of the narrated story complements the absence of such marks -uncommon in this register.

As for their location within the utterance, luego and después usually appeared at the beginning. However, a small number of cases (17 examples) were recorded of their presence in the middle -with a slight predominance of después $(52.94 \%, 9 / 17)$ - or at the end (5 examples) -where después clearly prevailed too $(80 \%, 4 / 5)$.

Claro, a partir de los años cuarenta, de mediados de siglo, empiezan los avances tecnológicos [...] La capacidad, luego, de la investigación aumenta terriblemente. (GC-10)

'Sure, after the forties, in the mid-century, technological advances begin [...] The capacity, then, of investigation increases terribly'.

$$
\begin{aligned}
& \text { y entonces como que va tomando conciencia uno de la problemática y } \\
& \text { las cosas que lo mueven; por supuesto que se va interpretando todo } \\
& \text { esto después, ¿ah?, se va analizando, se va interpretando. (CH-08) } \\
& \text { 'and then one becomes aware of the problems and the things that } \\
& \text { move him; of course all this is being interpreted later, ah?, it is being } \\
& \text { analysed, it is being interpreted'. }
\end{aligned}
$$

Another aspect examined in our study was the distribution of the variants luego and después in a single speaker. Our interest in this case focused on checking whether the most common trend is for one person to use only one of these two alternating units or whether it is more usual for that person to combine both of them. 


\begin{tabular}{ll}
\hline Only luego & 30 \\
Only después & 60 \\
Luego and después & 22 \\
& $\begin{array}{l}\text { Luego was preferred } \\
\text { Después was preferred }\end{array}$ \\
$\begin{array}{l}\text { The same number of } \\
\text { occurrences for luego and } \\
\text { después }\end{array}$ & 15 \\
\hline
\end{tabular}

Table 2. Distribution of luego and después as time connectors according to each speaker's usage

Our findings show that most of the respondents who adopted these connectors used only one of them (90/142,63.38\%), mainly después (60/90,66.67\%). However, among those who used the two variants, more respondents preferred luego (22/52, $42.31 \%$ ) as opposed to an identical percentage of informants who preferred después and used both forms to the same extent (15/52, 28.85\%). Consequently, while the overall data indicate that después is the most commonly used form, luego shows great vitality in competition with the other variant in a single speaker. This suggests that both forms are very widespread and scattered without a clear predominance of one over the other within the educated Hispanic norm. At times, both of them were even used on the same enumeration with no specific distribution pattern whatsoever being perceived.

$$
\begin{aligned}
& \text { Ahora, para eso debe existir un orden, que primero es mariposa, } \\
& \text { después viene dorso, luego pecho, y luego libre o crol. (ME-01) } \\
& \text { 'Now, there must be an order for that, first it is butterfly, then comes } \\
& \text { backstroke, then breaststroke, and then freestyle or crawl'. }
\end{aligned}
$$

It is also worth highlighting that a small group of 6 informants sometimes used the two of them together. A total of 19 examples were documented, always in the order luego después.

$$
\begin{aligned}
& \text { Luego, después, aún sin dejar de ser catedrático del seminario, profesor } \\
& \text { del seminario, quiso mi prelado, el cardenal Ilundain, que fuese yo } \\
& \text { también profesor de religión en la Escuela, casi acabada de formar o de } \\
& \text { perfeccionar, de Peritos Industriales. (SE-12) } \\
& \text { 'Then, later, even while being seminary professor, seminary teacher, my } \\
& \text { bishop, Cardinal Ilundain, wanted me too to be also a Religion teacher } \\
& \text { at the newly finished or perfected Industrial Engineers School'. }
\end{aligned}
$$

As a general rule, these speakers used this amalgamated version of both connectors more than once (all but 2 of them), so it seems to be a personal preference which cannot be extended to the majority of respondents. These individuals also utilised these connectors separately. With the exception of one man and one woman belonging to the second and the first generation respectively (CG-07 and ME-04), 
they were all third-generation informants. It can be added that a previous study about the speech of Seville (Santana in press) did not allow us to document any cases of luego después in the most recent materials (from recordings made between 2012 and 2013), which clearly points at a rare use in the high sociolect that will eventually tend to disappear.

The diatopical distribution of luego and después as time connectors in the Panhispanic educated speech norm can be seen in the table below:

\begin{tabular}{lllll}
\hline & \multicolumn{3}{c}{ Luego } & \multicolumn{3}{l}{ Después } \\
\cline { 2 - 5 } & $\mathbf{N}$ & $\mathbf{\%}$ & $\mathbf{N}$ & $\%$ \\
\hline BO & 13 & 38.24 & 21 & 61.76 \\
BA & 8 & 9.52 & 76 & 90.48 \\
CA & 9 & 33.33 & 18 & 66.67 \\
LP & 26 & 76.47 & 8 & 23.53 \\
GC & 35 & 40.70 & 51 & 59.30 \\
LI & 31 & 36.90 & 53 & 63.10 \\
MA & 74 & 62.71 & 44 & 37.29 \\
ME & 24 & 42.86 & 32 & 57.14 \\
CR & 28 & 52.83 & 25 & 47.17 \\
PR & 19 & 50.00 & 19 & 50.00 \\
CH & 5 & 12.50 & 35 & 87.50 \\
SE & 14 & 30.43 & 32 & 69.57 \\
\hline
\end{tabular}

Table 3. Diatopical distribution of luego and después as time connectors

Most cities join the general trend with a predominant use of después, except for La Paz, Madrid and San José de Costa Rica -though the difference is not significant in the latter. In turn, the other two cities did present a strong settlement of luego as a time connector. No common lines permitting to draw a distinction between the Spanish of Spain and that of Latin America are visible.

The fact that respondents were classified according to age and gender parameters has allowed us to make a number of sociolinguistic considerations. The analysis results reveal a preference for después in every age group as well as in both genders, which is actually in keeping with the general trend found in the Panhispanic educated norm. 


\begin{tabular}{lllll}
\hline & Luego & \multicolumn{3}{c}{ Después } \\
\cline { 2 - 5 } & $\mathbf{N}$ & \% & $\mathbf{N}$ & $\%$ \\
\hline 1 & 71 & 46.10 & 83 & 53.90 \\
2 & 126 & 41.45 & 178 & 58.55 \\
3 & 89 & 36.78 & 153 & 63.22 \\
\hline
\end{tabular}

Table 4. Distribution of luego and después as time connectors depending on age

\begin{tabular}{llll}
\hline $\begin{array}{l}\text { Luego } \\
\mathbf{N}\end{array}$ & \% & Después \\
\hline 93 & 36.76 & $\mathbf{N}$ & $\%$ \\
193 & 43.18 & 254 & 63.24 \\
\hline
\end{tabular}

Table 5. Distribution of luego and después as time connectors depending on gender

\section{Luego and Después as Information-Structuring Units}

This second textual function is directly related to the organisation of the informative structure. Its main role lies in facilitating text progression through the supply of data which are not only associated with the speaker's communicative intention but also conceived "como el resultado de respuestas a posibles preguntas de los interlocutores" 'as the result of answers to possible questions of interlocutors' (Portolés 2010: 284). Although these markers are more common in writing (Martin Zorraquino and Portolés 1999: 4086), it seems unthinkable to believe that they are not present in spontaneous speech. Quite the opposite, in fact, they acquire specific characteristics both in the type of forms used and in their distribution (Garcés 2008, Santana 2014).

Actually, luego and después are frequently used in the Hispanic educated norm as 'information structurers' -the percentage is lower than the one corresponding to their use as time connectors, though (496/1196, 41.47\%). In any case, their distribution among respondents is fairly scattered, since more than half of them used one of these units at least once $(104 / 168,61.90 \%)$. It is worth noting the small number of people who utilised these forms in Bogotá (only 2) and San Juan de Puerto Rico (only 4), also reflected in a low number of examples (2 and 10 respectively). Después was again the favourite variant for this function (283/496, $57.06 \%$ ) with a very similar percentage to that of luego.

The utilisation of luego and después as continuity-ordering units helped us to develop a subtopic within the text. In this regard, Martín Zorraquino and Portolés (1999: 4086) state that "presentan el conjunto de esta secuencia como un único comentario y cada parte como un subcomentario" "they present the whole of this 
sequence as a single comment and each of its parts as as a subcoment'. Many of the examples recorded in our materials illustrate this basic feature, generally in the form of enumerations where the parts or details of a previously announced idea are identified (10), or where a statement is supported on examples (11). It goes from general to particular.

\author{
Sí. Esta es una casa como las de antaño, ¿no?, de Caracas. Que todas las \\ casas de Caracas eran así: el corredor, el patio, el comedor, después el \\ otro pat... el corral... (CA-14) \\ 'Yes. This is a house like the ones from olden days from Caracas isn' $t$ it? All \\ the houses in Caracas were like this one: the corridor, the patio, the \\ dining room, then the other pat... the backyard...'. \\ Entonces, no impone uno sus ideas sobre el otro. Ahora, luego, \\ Humberto, por ejemplo, él va directamente a la parte de exteriores, ¿no?, \\ fachadas, un poco. (LP-10)' \\ So, one doesn't impose his ideas on the other. Now, then, Humberto, for \\ example, he goes directly to the outer part, right?, facades, a little'.
}

Indeed, they can be said to represent a variant of a particularly usual feature in nonelaborate orality, namely: exemplification. Speakers tend to particularise, to illustrate their explanations with data and examples which allow them to transmit information to their listeners as accurately as possible.

Despite the presence of this basic information-organising and distributing role in all corpus examples, it is also possible to perceive other contextual meanings which overlap with its basic 'continuation' nuance. Our research has specifically documented the contents of addition, contrast, opposition and conclusion.

Luego and después are very often used not only to introduce the segment that comes next; the interpretation of 'adding' a new piece of information is perceived as well. In these cases, the subtopic is widely assumed to develop through the accumulation of several elements, which are added to one another. They can be replaced by también or además -markers that are likely to occur in the 'immediate surroundings.' In fact, continuity marks imply the addition of a new element, which explains the repeated presence of this value inside the corpus.

\footnotetext{
Sakuska estaba en la calle de Alcalá, pasado... Correos, a mano derecha, estaba en un piso bajo; $y$ ahí estaba siempre muy elegante. Iba siempre la gente muy elegante. Luego había otro que todavía existe en la...

Claudio Coello, que se llama Tea Room. (MA-13)

'Sakuska was in the Alcala Street, past... Post office, on the right, it was on a lower floor; and there it was always very smart. People always dressed very smart. Then there was another that still exists in the...
} 
Claudio Coello, it is called Tea Room'.

Inf.- También, hacer el trabajo de recogebolas.

Enc.- Sí.

Inf.- Después también he practicado, ya no, pero... en cualquier momento también puedo reiniciar de nuevo, es en... tabla hawaiana, que es un deporte también muy saludable. En... se... se puede correr tabla en toda la temporada, ¿no?, todo el año. (LI-02)

'Inf.- I've also worked as a ball boy. // Enc.- Yes. // Inf.- Later I have also practiced, not anymore, but... anytime I can also restart again, it is in... Hawaian surfing, that is also a very healthy sport. In... you can surf the whole season, right?, the whole year'.

Secondly, it is quite common for luego and después to introduce a new aspect in the development of a subtopic that contrasts sharply with what has been said before. The content is distributed and divided into several parts, often two of them, and some kind of confrontation arises between them. It is a distributive-contrastive nuance which can be paraphrased using correlative formulas such as por otro lado, por otra parte... These markers have little presence in non-elaborate orality, as has been recently documented (Santana 2014). Nevertheless, they sometimes appeared around luego and después with this meaning.

Pues, en realidad, yo ahora con mis veintiséis... no me siento separado de ellos por once años, sino posiblemente en cuanto a mentalidad, esto de fondo, y luego, ya de forma, casi me da la impresión de que estoy separado por auténticos lustros de ellos. (MA-02)

'Well, actually, now I' $m$ twenty six... I don't feel separated from them by eleven years, but possibly mentally, but then, deep down, I almost get the impression that I'm separated by real decades from them'.

Entonces pues se creó una colección de estadísticas básicas, por ejemplo, y entonces se recogen estadísticas de un sector o de un subsector durante diez años, que se publica y entonces pues tienes, sobre todo, para el investigar y... que tienen una fuente de información bastante rica. Después, por otro lado, parecía también importante el mantener informada a la... al sector empresarial de una serie de parámetros de la economía... regional, (GC-07)

Then a collection of basic statistics was created, for example, and then statistics from a sector or a subsector are collected for ten years, are published which then you have, mainly, for researching and... they have a fairly rich source of information. Then, on the other hand, it seemed also important to keep... the business sector of a number of parameters of the regional economy... informed'. 
There are other instances in which the orientation of the segment that luego and después go with contradicts or opposes what has been previously said. This is a counter-argumentative meaning which could be paraphrased using pero or sin embargo (two markers often used in this context to reinforce that discursive value actually).

me gustó que... volver a la escuela. Después encontré tanta diferencia entre... la escuela de mi época y la escuela de ese momento... que me daba pena... y decía: "Se me está borrando la linda impresión que yo tenía de mi colegio". (BA-10)

'I liked that... going back to school. Then I found such a difference between...school from my time and school at that moment... that I was embarrassed... and I said, "It is wiping out the beautiful impression that I had about my school"'.

Entonces, de alguna forma... yo no sé si se debería de controlar o no, porque no lo sé, porque hay especialidades que, a lo mejor, pues en la... en medicina pública no encuentras trabajo, pero, luego, a nivel privado puedes conseguir trab... puedes for... formarte tu trabajo, montar una clínica privada, que funcionen, no como funcionan aquí. (GC-08)

'Then, somehow... I don't know if I should control it or not, because I don't know, because there are specialities that, maybe, in... in public medicine you can't find work, but, then, in private medicine you can... you can... get training in your work, set up a private clinic, that works, not in the way they work here'.

Conclusion is the fourth sense documented through our research work. The segment introduced by luego or después is understood as the summative closing of all the above. Both the content of statements and the lexical elements present in the context favour this interpretation.

Ha oído hablar de ellas, y había... escasez de comida, se notaba realmente y mucho. Y luego ya, pues nada, ambiente tranquilo, ambiente de colegio, ambiente de universidad... (MA-10) 'He has heard of them, and there was... shortage of food, it was really noticeable and so much. And then, since that time, nothing, a quiet atmosphere, a school atmosphere, a university atmosphere...'.

(19) No fui a la despedida, que fue una despedida a la que sí dije que asistía y tenía mi billete, pero sabemos lo que son los jet-foils, entonces me fui al aeropuerto, no pude conseguir avión y no me fui a despedir, pero no porque yo no quisiera, porque yo creo que la compostura y las formas hay que guardarlas siempre, ¿verdad?, pero después en el fondo digo: 


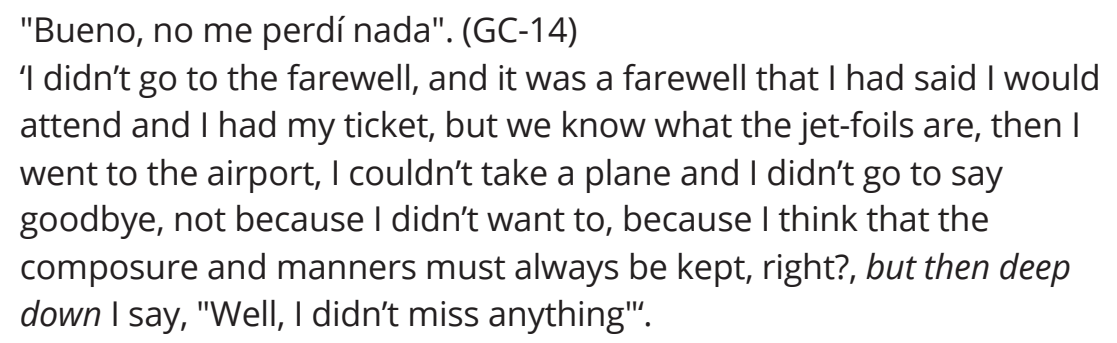

Just like it happened when they played the role of time connectors, luego and después as information-structuring units often appear on enumerations where it was also unusual for previous and subsequent statements to be identified by means of beginning or ending marks. This is, once more, a feature of non-elaborate orality. The use of explicit marks for that purpose was only documented in six cases throughout our research work. Most of the closing sequences were again $y+$ luego I después -in fact, all but one (which contained the specific marker por último).

$$
\begin{aligned}
& \text { Ha oído hablar de ellas, y había... escasez de comida, se notaba } \\
& \text { realmente y mucho. Y luego ya, pues nada, ambiente tranquilo, } \\
& \text { ambiente de colegio, ambiente de universidad... (MA-10) } \\
& \text { 'He has heard of them, and there was... shortage of food, it was really } \\
& \text { noticeable and so much. And then, since that time, nothing, a quiet } \\
& \text { atmosphere, a school atmosphere, a university atmosphere...'. }
\end{aligned}
$$

No fui a la despedida, que fue una despedida a la que sí dije que asistía y tenía mi billete, pero sabemos lo que son los jet-foils, entonces me fui al aeropuerto, no pude conseguir avión y no me fui a despedir, pero no porque yo no quisiera, porque yo creo que la compostura y las formas hay que guardarlas siempre, ¿verdad?, pero después en el fondo digo: "Bueno, no me perdí nada". (GC-14) 'I didn't go to the farewell, and it was a farewell that I had said I would attend and I had my ticket, but we know what the jet-foils are, then I went to the airport, I couldn't take a plane and I didn't go to say goodbye, not because I didn't want to, because I think that the composure and manners must always be kept, right?, but then deep down I say, "Well, I didn't miss anything"'.

With regard to placement, luego and después as continuity-ordering units precede the segment that they affect (Garcés 2008: 41). Only one case with a postponed location and another one inserted into the statement were found in our materials.

\footnotetext{
Pues ya le digo: en la Universidad Gregoriana, después, en ese primer curso estudiábamos la metafísica general, que nos daba el padre Pao... Pablo Dezza. Pablo Dezza era el rector de la Universidad Gregoriana. (ME-05)
} 
'Well, I tell you, at the Gregorian University, then, in the first course we studied general metaphysics, that was taught by Father Pao ... Pablo Dezza. Paul Dezza was the rector of the Gregorian University'.

Genética, primero; estructural, después, y después la categorial. ( $\mathrm{CH}-07)$

'Genetics, first; structural, then, and then categorical'.

Following the same pattern as in the case of time connectors, the next step in our study consisted in examining the utilisation of luego and después by each speaker.

Only luego 28

Only después

Luego and después

Luego was preferred

Después was preferred

The same number of occurrences for luego and después

Table 6. Distribution of luego and después as information-structuring units according to each speaker's usage

Most of the respondents who adopted these markers used exclusively one of the two variants $(75 / 104,72.12 \%)$, mainly después $(47 / 75,62.67 \%)$, although some people combined both forms $(29 / 75,38.67 \%)$ even on the same enumeration.

$$
\begin{aligned}
& \text { Metodistas, luego hay testigos de Jehová... del séptimo día, alguna } \\
& \text { religión relacionada... sí, después hay adventistas exactamente. (LP-08) } \\
& \text { 'Methodists, then there are Jehovah's Witnesses... of the seventh day, } \\
& \text { some related religion... yes, then there are Adventists exactly'. }
\end{aligned}
$$

Examples of the two forms grouped were also identified this time; a total of 6 cases distributed between three informants from the second generation and three from the third one. All but one were utilised by two speakers who had also adopted this grouped formula in the role of time connectors, which seems to suggest that this stylistic variant is only common among some informants and does not usually appear within younger age groups.

(25) Pues eso; por las mañanas se paseaba uno por la Castellana, los domingos por la mañana. Y luego, después entre las amistades, los amigos, pues ya conocían hijos de amigos nuestros, ellos conocían a otros amigos, nos los presentaban, y nos reuníamos. (MA-13) You walked along the Castellana in the mornings, on Sunday mornings. And then, later among friends, the friends, because they already knew our friends' children, they knew other friends, they introduced them to us, and we met'. 
As for diatopical distribution, even though después was more often used than luego in the Hispanic educated norm with the role of continuity-ordering unit, the data breakdown reveals that luego shows a greater frequency with this function in La Paz, in Mexico and particularly in Madrid.

\begin{tabular}{lllll}
\hline & \multicolumn{3}{c}{ Luego } & \multicolumn{3}{l}{ Después } \\
\cline { 2 - 5 } & $\mathbf{N}$ & $\mathbf{\%}$ & $\mathbf{N}$ & $\mathbf{\%}$ \\
\hline BO & 1 & 50.00 & 1 & 50.00 \\
BA & 2 & 5.41 & 35 & 94.59 \\
CA & 3 & 14.29 & 18 & 85.71 \\
LP & 24 & 64.86 & 13 & 35.14 \\
GC & 23 & 26.14 & 65 & 73.86 \\
LI & 19 & 25.68 & 55 & 74.32 \\
MA & 99 & 83.19 & 20 & 16.81 \\
ME & 18 & 78.26 & 5 & 21.74 \\
CR & 10 & 37.04 & 17 & 62.96 \\
PR & 2 & 20.00 & 8 & 80.00 \\
CH & 0 & 0.00 & 28 & 100.00 \\
SE & 12 & 40.00 & 18 & 60.00 \\
\hline
\end{tabular}

Table 7. Diatopical distribution of luego and después as information-structuring units

If the analysis is performed by age groups and by gender, después emerges as the preferred variant in every social group once again. Utilisation rates were very similar in the first and second generations.

\begin{tabular}{lllll}
\hline & Luego & \multicolumn{3}{c}{ Después } \\
& $\mathbf{N}$ & $\%$ & $\mathbf{N}$ & $\%$ \\
\hline 1 & 61 & 46.56 & 70 & 53.44 \\
2 & 112 & 49.34 & 115 & 50.66 \\
3 & 40 & 28.99 & 98 & 71.01 \\
\hline
\end{tabular}

Table 8. Distribution of luego and después as information-structuring units depending on age

\begin{tabular}{lllll}
\hline & Luego & \multicolumn{3}{c}{ Después } \\
& $\mathbf{N}$ & $\%$ & $\mathbf{N}$ & $\%$ \\
\hline $\mathrm{H}$ & 69 & 41.07 & 99 & 58.93 \\
$\mathrm{M}$ & 144 & 43.90 & 184 & 56.10 \\
\hline
\end{tabular}

Table 9. Distribution of luego and después as information-structuring units depending on gender 


\section{Conclusions}

The analysis of luego and después with a textual function in the Hispanic educated norm has allowed us to verify their great vitality both as time connectors and as information-structuring units. Our research documented a higher number of cases where they acted as time connectors (58.53\%) -often used in non-elaborate orality as resources to describe a fact or event that happened subsequently to another which occurred or had been narrated before. This has also been favoured by the eminently 'narrative-descriptive' nature of our sample. In fact, their use was quite widespread among educated speakers, since one of the two variants was used at least once by $84.52 \%$ of our respondents. These markers basically fulfil the function of signalling chronological succession and tend to be accompanied by lexical forms delimiting the time frame to which they refer. They mostly appeared preceding the segment that they influence and it was common for them to be utilised in unmarked enumerations that highlighted the first or last event in a series -a regular feature of non-elaborate speech.

Studying their variation as time connectors allowed us to learn that después was generally the preferred form (59.14\%) -though with percentages very close to those of luego. Nevertheless, the distribution across cities showed that Madrid, San José de Costa Rica and mainly La Paz presented higher usage rates for luego. The distribution by age and gender made visible a preference for después in every social group, which leads us to conclude that it is the most consolidated variant when it comes to fulfilling this textual role -despite the equally wide presence of luego across the corpus.

One more step in the grammaticalisation of these two elements makes them become information-structuring units which have turned the nuance of chronological succession into that of continuity in the arrangement of subtopics. Luego and después give way to the enunciation of contents through which discourse can progress. They often enter data or examples with which the speaker supports a previous statement, going from general to particular. Some discursive values overlap with this basic content: addition (information is added); distribution-contrast (several aspects of the same general idea are contrasted); opposition (a segment is introduced with an opposite orientation to what has been said before); and conclusion (the new statement has a summative nature and exposes what is inferred or concluded from the preceding statements). The most widespread sense among those examined in our sample was addition, followed by contrast -not surprisingly, since they are closely linked to the notion of continuity which defines luego and después as information-structuring units. Once again, the preferred placement was at the beginning of the segment on which they exert an influence; and it was unusual to find beginning or ending markers when they formed part of 
enumerations. Non-elaborate orality shows a preference for stressing the succession of elements in a subtopic, and much less importance is assigned to making an elaborate distribution with an opening, development and closing. The actual sequencing of contents, together with the lexical elements present in the context, nearly always fulfils this function.

The quantitative analysis showed that they appear less frequently as continuityordering units than as time connectors (41.47\%) in the educated norm materials, although the reported cases were rather widespread among a large number of respondents (61.90\%). Again, the preferred variant was después (57.06\%) -a recurrent feature in most of the cities under study; the exceptions were La Paz, Mexico and Madrid, where luego had more vitality. The distribution according to age and gender variables provided no meaningful data, insofar as después predominated in every case.

Luego and después are strategies with a considerable presence in the discursive 'physiognomy' of oral texts. Their recurrent use, mainly on enumerations, contributed to give a particular appearance to non-elaborate spoken language. The ideas are arranged, the same as in planned texts, but it is more important to highlight the chronological succession or continuity of information than other more specific forms which can indicate the order of elements in a series. Both variants are fairly evenly distributed among speakers -después being slightly predominant, though. They are two equivalent units which alternate without being influenced by any linguistic or social factors. Our study has only detected a certain degree of influence being exerted by the spatial factor with regard to the distribution of these two markers. More precisely, luego was preferred in Madrid for the two textual functions analysed. A contrast should definitely be drawn with other materials from northern Spanish speech with the aim of checking whether or not this is a widespread trend in that Spanish-speaking area.

\section{About the author}

Juana Santana Marrero es profesora titular del área de Lengua Española en la Universidad de Sevilla. Imparte docencia en dos másteres de investigación en la Universidad Hispalense (Máster en Estudios Hispánicos Superiores y Máster en Enseñanza del Español como Lengua Extranjera y de Otras Lenguas Modernas) y uno en la UNED (Máster en Análisis Gramatical y Estilístico del Español).

Es responsable del Grupo de Investigación Sociolingüística Andaluza: Estudio Sociolingüístico del Habla de Sevilla HUM-141 y coordina la participación de esta 
ciudad en los proyectos internacionales La Norma Culta Hispánica Juan M. Lope Blanch y Proyecto de Estudio Sociolingüístico del Español de España y América (PRESEEA). Sus principales líneas de investigación se centran en el análisis de la variación gramatical y de la variación léxica, principalmente en el habla de Sevilla; el uso discursivo oral de las construcciones gramaticales y sintácticas; y las relaciones entre la norma y el uso en los medios de comunicación. Estas líneas se concretan en el estudio de una amplia variedad de fenómenos gramaticales (marcadores del discurso, adverbios, género, oraciones relativas, oraciones condicionales, perífrasis verbales y gerundio) y léxicos (anglicismos y campo semántico de la alimentación).

Ha publicado una monografía: Las oraciones condicionales. Estudio en la lengua hablada (Universidad de Sevilla, 2003), es coeditora de tres volúmenes y dirige la colección Sociolingüística Andaluza. Asimismo es autora de unos treinta trabajos, entre artículos de revistas y capítulos de libro. En el primer caso, las contribuciones han visto la luz en revistas de carácter internacional (Boletín de Lingüística, Caracas; Cuadernos de ALFAL, Santiago de Chile; Anuario de Letras, México) y nacional (RILCE, Oralia, Lingüística Española Actual, Español Actual, Philologia Hispalense). Las colaboraciones como capítulos de libro se encuentran en editoriales como Arco/Libros, Iberoamericana/Vervuert, Max Niemeyer Verlag, Universidad Autónoma de México, entre otras. Ha intervenido con comunicaciones o conferencias en más de veinticinco foros científicos que han tenido lugar en instituciones españolas y extranjeras.

\section{Article history}

Paper received: 24th September 2014

Paper received in revised form and accepted for publication: 12th May 2015

\section{References}

Carbonero, Pedro and Juana Santana. (2010). Los marcadores y la variación espacial y social. In Óscar Loureda and Esperanza Acín (Coords.), La investigación sobre marcadores del discurso del español, hoy (497-521). Madrid: Arco/Libros.

Cortés, Luis. (1988). Marcadores del discurso y análisis cuantitativo. In María Antonia Martín Zorraquino and Estrella Montolío (Coords.), Los marcadores del discurso. Teoría y análisis (143-160). Madrid: Arco/Libros. 
Cortés, Luis and Matilde Camacho. (2005). Unidades de segmentación y marcadores del discurso. Madrid: Arco/Libros.

Fuentes, Catalina. (1996). La sintaxis de los relacionantes supraoracionales. Madrid: Arco/Libros.

Fuentes, Catalina. (2009). Diccionario de conectores y operadores del español. Madrid: Arco/Libros.

Garcés, María Pilar. (1996). La enumeración en el discurso oral. Español Actual 66: 53-62.

Garcés, María Pilar. (2000). La ordenación del discurso: series correlativas. In José Jesús de Bustos, Patrick Charaudeau, José Luis Girón, Silvia Iglesias and Carmen López (Eds.), Lengua, discurso, texto: I Simposio internacional de análisis del discurso, vol. 1 (551-564). Madrid: Visor.

Garcés, María Pilar. (2001). Marcadores de continuidad en el discurso oral. In Isabel de la Cruz Cabanillas (Ed.), La lingüística aplicada a finales del siglo XX: ensayos y propuestas, ed., vol. 2 (543-548). Asociación Española de Lingüística Aplicada. Alcalá de Henares: Servicio de Publicaciones de la Universidad.

Garcés, María Pilar. (2008). La organización del discurso: marcadores de ordenación y de reformulación. Madrid/Frankfurt: Iberoamericana/Vevuert.

Kovacci, Ofelia. (1999). El adverbio. In Ignacio Bosque and Violeta Demonte (Eds.), Gramática descriptiva de la lengua española, vol. 1 (705-786). Madrid: Espasa Calpe.

Loureda, Óscar and Esperanza Acín. coords. (2010). La investigación sobre marcadores del discurso del español, hoy. Madrid: Arco/Libros.

Martín Zorraquino, María Antonia. (2006). Los marcadores del discurso en español: balance y perspectivas para su estudio. In Manuel Casado, Ramón González and María Victoria Romero (Coords.), Lengua, cultura, valores. Actas del I congreso internacional de análisis del discurso (43-64). Madrid: Arco/Libros.

Martín Zorraquino, María Antonia and José Portolés. (1999). Los marcadores del discurso. In Ignacio Bosque and Violeta Demonte (Eds.), Gramática descriptiva de la lengua española, vol. 3 (4051-4421). Madrid: Espasa-Calpe.

Moliner, María. (1998). Diccionario de uso del español ( $2^{\text {nd }}$ ed). Madrid: Gredos.

Portolés, José. (2010). Los marcadores del discurso y la estructura informativa. In Óscar Loureda and Esperanza Acín (Coords.), Los estudios sobre marcadores del discurso en español, hoy (281-325). Madrid: Arco/Libros.

Real Academia Española. (2001). Diccionario de la lengua española (22 ${ }^{\text {nd }}$ ed.). Madrid: EspasaCalpe.

Real Academia Española. (2009). El adverbio y el grupo adverbial. In Nueva gramática de la lengua española, vol. 2 (2285-2394). Madrid: Espasa Calpe.

Samper, José Antonio. (2005). Macrocorpus para el estudio de la norma lingüística culta. Oralia 8: 105-122.

Samper, José Antonio, Clara Eugenia Hernández and Magnolia Troya. (2008). Macrocorpus de 
la norma lingüística culta de las principales ciudades del mundo hispánico. Las Palmas de Gran Canaria: Servicio de Publicaciones y Difusión Científica de la Universidad de Las Palmas de Gran Canaria.

Santana, Juana. (2014). Marcadores del discurso de Sevilla. Cuadernos de la ALFAL 5. Marcadores discursivos en la norma culta hispánica: 1964-2014, coord. Alba Valencia, 277311. Santiago de Chile.

Santana, Juana. In press. Luego y después: uso discursivo y variación. RILCE. Revista de Filología Hispánica.

Santos, Luis. (2003). Diccionario de partículas. Salamanca: Luso-Española de Ediciones.

Seco, Manuel, Olimpia Andrés and Gabino Ramos. (2011). Diccionario del español actual, $2^{\text {nd }}$ ed., 2 vols. Madrid: Santillana.

Valencia, Alba. (Coord.) (2014). Cuadernos de la ALFAL 5. Marcadores discursivos en la norma culta hispánica: 1964-2014. Santiago de Chile. 